http://dx.doi.org/10.15762/ZH.2015.36

ANNA STACHOWSKA-KRZYŻANKOWSKA

(Instytut Historii PAN)

\title{
CHRZTY SZLACHECKIE W PARAFII LUZINO W DRUGIEJ POŁOWIE XVIII WIEKU
}

Słowa kluczowe: demografia staropolska, rodzina drobnoszlachecka, nowożytność, Kaszuby, genealogia, drobna szlachta, rejestracja metrykalna, staropolskie metryki chrztów

Praca ta stanowi kontynuację badań nad genealogią i demografią kaszubskiej rodziny drobnoszlacheckiej w dobie nowożytnej. Zapoczątkowała ją opublikowana wcześniej analiza ślubów szlacheckich z parafii luzińskiej ${ }^{1}$. Opracowanie i szczegółowa analiza źródeł metrykalnych dzięki wychwyceniu wszelkich informacji dotyczących osób nobilitowanych ma ułatwić rekonstrukcję rodzin szlacheckich dawnego powiatu puckiego i mirachowskiego, dać pogląd na ich funkcjonowanie, wzajemne relacje i obyczajowość poszczególnych rodzin, a przede wszystkim umożliwić prześledzenie procesów demograficznych zachodzących w tej grupie społecznej.

Zapisy metrykalne dokumentujące egzystencję poszczególnych jednostek służyły pierwotnie celom administracyjnym. W ten sposób ewidencjonowano i poddawano kontroli najważniejsze momenty życia chrześcijanina, to jest sakrament chrztu, małżeństwa oraz śmierć. Mimo że źródła te stanowią bogaty materiał niezbędny do obserwacji przemian demograficznych, a także zawierają cenne informacje użyteczne w badaniach onomastyczno-historycznych, stopień ich wykorzystania jest ciągle stosunkowo niski².

Termin „metryka”, pochodzący od łacińskiego słowa metricula oznaczającego spis, regest, katalog ${ }^{3}$, w przeszłości najczęściej stosowany był w nomenklaturze sądowniczo-kancelaryjnej jako określenie kościelnych i świeckich spisów urzędowych, ksiąg wpisów (np. Metrica Regni Poloniae), inwentarzy i innych tego

${ }^{1}$ Anna StachowsKa-Krzyżankowska, Małżeństwa szlacheckie $w$ parafii Luzino $w$ latach 1670-1797 w świetle ksiag metrykalnych (przyczynek do dziejów szlachty kaszubskiej), Zapiski Historyczne, t. 79: 2014, z. 3, s. 115-140.

${ }^{2}$ Radosław Kотескі, Rejestracja metrykalna wiernych $w$ świetle potrydenckiego ustawodawstwa Kościoła Katolickiego (ze szczególnym uwzględnieniem prawodawstwa diecezji Chełmińskiej, Gnieźnieńskiej, Płockiej i Włocławskiej), Nasza Przeszłość, t. 112: 2009, s. 136-137.

${ }^{3}$ Karolina Korenda, Chrzty w parafii Pszczew w latach 1632-1667, Rocznik Lubuski, t. 27: 2001, cz. 2, s. 66 . 
typu wykazów ${ }^{4}$. Genezę rejestracji metrykalnej, w takim znaczeniu, w jakim rozumiemy ją współcześnie, upatruje się we wczesnochrześcijańskich katalogach ochrzczonych i katechumenów, a także w spisach zmarłych. Zwyczaj ewidencji wiernych został jednak przez Kościół dość wcześnie zarzucony. W Europie Zachodniej do prowadzenia zapisów metrykalnych powrócono w pierwszej połowie XIV w. Za najstarszą uważa się rejestrację chrztów z włoskiego Arezzo z 1314 r., a także z Cremony (1369) i Sieny (1379). Równie stare są metrykalia niektórych parafii niemieckich (Rheine (1345), Münster (1403), Endersdorf (1415)). Za najstarszą we Francji przyjmuje się rejestrację metrykalną parafii Givry (Saône-et-Loire), w której zachowały się księgi pogrzebów od 1334 r. i ślubów od 1336 r.5 $\mathrm{Z}$ połowy XV w. pochodzi pierwsza wzmianka używająca na ziemiach polskich terminu „metryka” w stosunku do spisów nupturientów ${ }^{6}$. W 1459 r. w statutach biskupa Tomasza Strzępińskiego zawarto przepisy dotyczące prowadzenia rejestru nowożeńców w parafiach diecezji krakowskiej ${ }^{7}$. W Polsce najstarsze zachowane katolickie źródła metrykalne pochodzą właśnie z terenu Małopolski i są to księgi ślubów z krakowskiego kościoła Najświętszej Marii Panny (od 1548 r.) oraz metrykalia parafii w Bochni (od 1559 r. $)^{8}$. Obowiązek powszechnej rejestracji chrztów i małżeństw w Kościele katolickim wprowadził dopiero sobór trydencki w listopadzie 1563 r., nakazując plebanom staranne prowadzenie i przechowywanie ksiąg metrykalnych. W Polsce do końca lat siedemdziesiątych XVI w. potwierdzały ten obowiązek synody zwoływane w poszczególnych diecezjach. Synod piotrkowski, który rozciągnął obowiązek prowadzenia rejestracji metrykalnej na całą Rzeczpospolitą, nakazał dodatkowo prowadzenie ksiąg bierzmowanych, przystępujących do komunii wielkanocnej oraz tzw. status animarum. Nakaz prowadzenia ksiąg zmarłych wprowadzil dopiero w 1614 r. Rytuat rzymski (a w Polsce Rytuał Piotrkowski w 1631 r.) $)^{9}$. Osobną kwestią pozostaje rzetelność i jakość prowadzenia rejestracji metrykalnej, na którą wpływ miało wiele czynników, w tym osobiste cechy poszczególnych duszpasterzy, ich kwalifikacje i wykształcenie ${ }^{10}$. Sytuacja polityczna, w jakiej znalazła się Rzeczpospolita w epoce nowożytnej, liczne wojny i epidemie, nie sprzyjały regularnemu i rzetelnemu prowadzeniu metryk, do czego nawoływały duchowieństwo parafialne kolejne synody i listy pasterskie zarówno w XVII, jak i w XVIII w. W efekcie rzeczywiste prowadzenie zapisów ochrzczonych, zaślubionych i zmarłych upowszechniło się na terenach polskich dopiero w pierwszej połowie XVIII w. ${ }^{11}$

${ }^{4}$ R. Котескі, op.cit, s. 141-142.

${ }^{5}$ Cezary Kuklo, Demografia Rzeczypospolitej przedrozbiorowej, Warszawa 2009, s. 91.

${ }^{6}$ R. KотескI, op.cit., s. 142.

${ }^{7}$ Włodzimierz Dworzaczek, Genealogia, Warszawa 1959, s. 59.

${ }^{8}$ C. KuKLo, op.cit., s. 91.

${ }^{9}$ Ibid., s. 91-93.

${ }^{10}$ Karolina Korenda, Rejestracja metrykalna parafii Pszczew z XVII wieku, Przeszłość Demograficzna Polski, t. 24: 2003, s. 49.

${ }^{11}$ C. KuKLo, op.cit. 
Dla parafii luzińskiej zachowały się metrykalia pochodzące z pierwszej połowy XVII w. ${ }^{12}$ Najstarsza księga chrztów przechowywana jest w Sächsisches Staatsarchiv Abteilung Deutsche Zentralstelle für Genealogie w Lipsku' ${ }^{13}$. Podstawą źródłową prowadzonych tu rozważań jest kolejna z zachowanych ksiąg, obejmująca lata 1758-1797, znajdująca się w zasobach Archiwum Archidiecezjalnego w Gdańsku ${ }^{14}$.

Luzino to duża wieś położona w środkowej części województwa pomorskiego, $\mathrm{w}$ powiecie wejherowskim, oddalona o nieco ponad $10 \mathrm{~km}$ od miasta powiatowego ${ }^{15}$. Wieś jest siedzibą parafii pod wezwaniem św. Wawrzyńca, której zasięg nie ulegał większym przekształceniom na przestrzeni wieków ${ }^{16}$. W dawnej Rzeczypospolitej parafia luzińska położona była na granicy powiatów puckiego i mirachowskiego. Do powiatu mirachowskiego przynależało Barłomino i Milwino, a pozostałe wsie leżały w obrębie powiatu puckiego ${ }^{17}$.

Pierwszy kościół w Luzinie ufundowały w połowie XIII w. norbertanki z Żukowa, a pojawiająca się w 1312 r. wzmianka o plebanie luzińskim sugeruje, że już na początku XIV w. funkcjonowała tu zorganizowana struktura parafialna ${ }^{18}$.

Osiemnastowieczne wsie podlegające tej parafii zamieszkiwała głównie ludność kaszubska. Siedemnasto- i osiemnastowieczne rejestry podatkowe wymieniają przede wszystkim osoby pochodzenia szlacheckiego (oraz nieliczną grupę zagrodników i wyrobników uiszczających podatki ze swoich ogrodów), posiadające przeważnie niewielkie areały ziemi w poszczególnych wsiach, co oznacza, że już wtedy tamtejszą szlachtę można było w większości zaliczyć do warstwy drobnoszlacheckiej ${ }^{19}$.

Pełniejsze dane o liczebności parafii przynosi wizytacja biskupia z 1766 r. Do komunii wielkanocnej przystąpiło wtedy 1314 osób (660 mężczyzn i 668 kobiet). Do tego odnotowano 522 katolickich dzieci (260 chłopców i 262 dziewczynki). W tym czasie w parafii było 192 dorosłych protestantów ( 97 mężczyzn i 95 kobiet) oraz 97 luterańskich dzieci (45 chłopców i 52 dziewczynki). Z powyższych danych wynika, że w połowie XVIII w. populacja parafii wynosiła 2125 osób. W 1780 r. liczba ludności nieco spadła i wynosiła 2077 osób: 1793 katolików (w tym 1240 osób dorosłych) i 284 luteranów ${ }^{20}$.

\footnotetext{
${ }^{12}$ Chrzty od 1630 r., małżeństwa od 1669 r., pogrzeby od 1758 r.

${ }^{13} \mathrm{http} / /$ www.westpreussen.de/cms/ct/kirchenbuecher/quellen.php?ID=517 (dostęp z 5 VII 2015 r.).

${ }^{14}$ Archiwum Archidiecezjalne w Gdańsku (dalej cyt. AAG), Parafia katolicka w Luzinie, sygn. W905.

${ }^{15}$ Jarosław ElLert, Kaszuby. Przewodnik turystyczny, Gdynia 2003, s. 84.

${ }^{16}$ Zbigniew Klotzke, Parafia i kościół pod wezwaniem św. Wawrzyńca w Luzinie, Luzino 2002, s. 15-25; idem, Kębłowo. Wieś i parafia, Luzino 2006, s. 19.

${ }^{17}$ Wacław Odyniec, Jerzy GodLewski, Ziemia Pucka. Przeszłość i teraźniejszość, Gdańsk 1974, s. 31.

${ }^{18}$ Gerard Labuda, Dzieje wsi Luzino, Luzino-Gdańsk 1995, s. 57.

${ }^{19}$ Ibid., s. 76, 84-88.

${ }^{20}$ Ibid., s. 107-109.
} 
Zasięg terytorialny luzińskiej parafii nie zmieniał się właściwie od jej erygowania aż do połowy ubiegłego stulecia. U progu badanego okresu, czyli w połowie XVIII w. do parafii należało kilkanaście wsi i kilka mniejszych osad: Luzino z młynem, Wyszecino z młynem, Barłomino z młynem i hutą, Strzebielino, Kębłowo z młynem i karczmą, Gościcino z młynem, Zielony Dwór, Robakowo, Gowino Wielkie, Gowino Małe, Dąbrówka, Ustarbowo z młynem, Sopieszyno z Borową karczmą, Przetoczyno z karczmą Wygoda, Częstkowo, Milwino z hutą, Sosnowa Góra $^{21}$ oraz Sępowskie, Królewskie i Kozłowskie ${ }^{22}$.

Do momentu sekularyzacji w 1773 r. Luzino należało do klasztoru żukowskiego ${ }^{23}$. Przetoczyno i Barłomino były własnością królewską ${ }^{24}$, jednak w wyniku nadań królewskich Barłomino przeszło w ręce Lubockich. Z czasem z Kębłowem, Tyłowem i Lubocinem utworzyło kompleks dóbr będących w posiadaniu rodziny Czapskich. W XVIII w. Barłomino należało do Krokowskich, a następnie do generała majora Karola Ludwika Schachmanna i Grumbkow-Grąbczewskich. Kębłowo z Lubocinem i Tyłowem w 1758 r. stało się własnością Ignacego Franciszka Przebendowskiego ${ }^{25}$, który był także właścicielem Ustarbowa i Sopieszyna.

Pozostałe wsie leżące w obrębie parafii stanowiły własność drobnoszlachecką ${ }^{26}$, o rozbudowanej, wielodworczej strukturze. Problem stosunków własnościowych został szczegółowo omówiony w pracy poświęconej małżeństwom szlacheckim tejże parafii ${ }^{27}$.

Według przepisów prawa kościelnego osobą udzielającą sakramentu chrztu świętego mógł być tylko kapłan. Jak podaje Cezary Kuklo, jedynie w szczególnych wypadkach chrztu mógł udzielić inny człowiek, także poganin lub heretyk, o ile zachowane zostały prawa i intencje kościelne związane $\mathrm{z}$ tym sakramentem ${ }^{28}$. $\mathrm{Z}$ zapisów w luzińskiej liber baptisatorum wynika, że chrzest dzieciom szlacheckim, podobnie jak potomstwu całej społeczności parafialnej, udzielany był przede wszystkim przez proboszczów: Grzegorza Adama Prądzyńskiego, który w metrykach występuje jako Grzegorz Plutowski ${ }^{29}$, Andrzeja Piechowskiego, Jakuba Kreffta ${ }^{30}$,

\footnotetext{
${ }^{21}$ Ad historiam ecclesiasticam Pomeraniae apparatus pauper [...] collectus ad interim a Georgio Schwengel, Cartusiae priore 1749, curavit Bruno CzAPLA (Fontes Towarzystwa Naukowego w Toruniu, t. 16-19), Toruń 1912-1915, s. 229-230; G. LABUdA, op.cit., s. 57.

${ }^{22}$ A. STACHOWSKA-KrZYŻanKowsKa, op.cit., s. 119.

${ }^{23}$ Paweł Czaplewski, Majątki duchowne sekularyzowane po 1772 r. w obrębie województwa pomorskiego i Wolnego Miasta Gdańska, Rocznik Gdański, t. 7-8: 1935, s. 402-403.

${ }^{24}$ Lustracja województw Prus Królewskich 1765, t. 1: Województwo pomorskie, cz. 1: Powiaty pucki i mirachowski, wyd. Jerzy DyGdAŁA, Toruń 2000, s. 49-50, 86-88.

${ }^{25}$ G. Labuda, op.cit., s. 122-123; Franz Schultz, Geschichte der Kreise Neustadt und Putzig, Gdańsk 1907, s. 407-409, 448-450.

${ }^{26}$ Krzysztof Mikulski, Osadnictwo wiejskie województwa pomorskiego od połowy XVI do końca XVII wieku, Toruń 1994, s. 161-171.

${ }^{27}$ A. STACHOWSKA-KRZYŻANKOWSKA, op.cit., s. 119-123.

${ }^{28}$ C. Kuklo, op.cit., s. 314-315.

${ }^{29}$ Tomasz NowICKI, Słownik biograficzny rządców parafii archidiakonatu pomorskiego w XVIII wieku, Lublin 2003, s. 175; A. STACHOWSKA-KRZYŻANKOWsKA, op.cit., s. 117-118.

${ }^{30}$ T. NOWICKI, op.cit., s. 258.
} 
i wikarych tejże parafii: Wojciecha Rykowskiego, Franciszka Wejera, Wawrzyńca Michnowskiego, Józefa Michała Gościckiego, Franciszka Torlińskiego i Franciszka Piechowskiego. Spotykamy też szereg innych duchownych. Pierwszy wpis w księdze datowany jest na 16 V 1758 r. Została wtedy ochrzczona Konstancja Józefina, córka szlachetnego Józefa Skwarcza i jego żony Barbary z Czaplewskich. Dziecko ochrzcił Grzegorz Plutowski, określony w dokumencie jako „proboszcz luziński”, mimo że formalnie plebanem został dopiero 18 VI 1758 r. ${ }^{31}$ Od maja do lipca $1758 \mathrm{r}$. dzieci luzińskie chrzcił m.in. Józef Bobrucki, komendariusz luziński, wcześniejszy wikariusz tejże parafii ${ }^{32}$, który 10 VII 1758 r. jest już określony jako „proboszcz grabowski" ${ }^{33}$. Poza wymienionymi chrztów dzieciom szlacheckim udzielała spora rzesza zakonników, przede wszystkim z klasztoru wejherowskiego, często wymienionych jedynie z imienia, a także Marcin Antoni Pellowski, proboszcz z Grabowa, i Krzysztof Zynda, komendarz rozłaziński. W 1793 r. córkę Franciszka Wyszeckiego i Katarzyny ze Słuszewskich ochrzcił Józef Tempski, komendariusz gniewski.

Wpisy w analizowanej księdze zawierają datę chrztu, miejsce urodzenia, imię dziecka, imię, nazwisko oraz pozycję społeczną ojca, imię matki, informację o pochodzeniu z prawego lub nieprawego łoża oraz personalia i pochodzenie chrzestnych. Początkowo sporadycznie odnotowywano nazwisko panieńskie matki. Wyjątkiem były nazwiska matek dzieci nieślubnych. W latach 1774-1782 nazwiska rodowe szlachcianek wpisywano dość regularnie. Następnie przez kolejne sześć lat informacja ta występuje sporadycznie. Od 1789 r. nazwisko rodowe matki znów zaczęto wpisywać do ksiąg. Początkowo dotyczyło to przede wszystkim chrztów szlacheckich, jednak pod koniec badanego okresu stało się regułą dla wszystkich chrztów.

Informację o wyznawanej religii wpisywano zazwyczaj tylko wtedy, gdy jedno lub oboje rodzice byli wyznania luterańskiego.

\section{LICZBY CHRZTÓW}

Dla uzyskania adekwatnych wyników badań konieczne jest krytyczne podejście do analizowanego źródła. Najprostszym sposobem na sprawdzenie kompletności metryk jest obliczenie liczby chrztów przypadających na jeden ślub. Dla drugiej połowy XVIII w. współczynnik ten powinien się zawierać w przedziale między 4,5 a 5,034. W przypadku całej parafii luzińskiej wynosi 4,8 , w związku z czym można przyjąć, że metryki te są kompletne. Na nieco niższym poziomie, aczkolwiek ciągle mieszczącym się w podanym przedziale, kształtuje się współczynnik metryk szlacheckich, wynosi on bowiem 4,7 .

\footnotetext{
${ }^{31}$ Ibid., s. 175 .

${ }^{32}$ Ibid., s. 43-44.

${ }^{33}$ AAG, Parafia katolicka w Luzinie, sygn. W905, k. 1v.

${ }^{34}$ K. KoRENDA, Rejestracja metrykalna, s. 50.
} 
W latach 1758-1797 w Luzinie odnotowano 3075 chrztów, w tym nieco ponad 15\% (462 wpisy) to chrzty szlacheckie ${ }^{35}$. Wartości procentowe odnoszące się do chrztów warstwy nobilitowanej pokrywają się z tymi, które obliczono w przypadku małżeństw, gdzie udział procentowy ślubów szlacheckich w stosunku do całkowitej liczby małżeństw zawartych w drugiej połowie XVIII w. wyniósł 15,3\% ${ }^{36}$.

Analizując średnią roczną liczbę chrztów w poszczególnych pięcioletnich okresach, można zauważyć spore zróżnicowanie. Początkowa tendencja wzrostowa osiąga swój szczyt pod koniec lat sześćdziesiątych, po czym przez kolejne 10 lat następuje spadek liczby urodzeń. Kolejne lata ponownie wykazują wzrost, z wyjątkiem niewielkiego wahnięcia na początku lat dziewięćdziesiątych.

Tabela 1. Chrzty w parafii Luzino w latach 1758-1797

\begin{tabular}{|c|c|c|c|c|}
\hline Lata & $\begin{array}{c}\text { Liczba wszystkich } \\
\text { chrztów }\end{array}$ & Średnia roczna & $\begin{array}{c}\text { Liczba chrztów } \\
\text { szlacheckich }\end{array}$ & Średnia roczna \\
\hline $1758-1762$ & 334 & 66,8 & 37 & 7,4 \\
\hline $1763-1767$ & 436 & 87,2 & 54 & 10,8 \\
\hline $1768-1772$ & 370 & 74 & 46 & 9,2 \\
\hline $1773-1777$ & 328 & 65,6 & 62 & 12,4 \\
\hline $1778-1782$ & 403 & 80,6 & 77 & 15,4 \\
\hline $1783-1787$ & 420 & 84 & 62 & 12,4 \\
\hline $1788-1792$ & 386 & 77,2 & 64 & 12,8 \\
\hline $1793-1797$ & 398 & 79,6 & 60 & 12 \\
\hline
\end{tabular}

Źródło: AAG, Parafia katolicka w Luzinie, sygn. W905 ${ }^{37}$.

W przypadku chrztów szlacheckich średnia roczna w poszczególnych okresach wykazuje dużo większą stabilizację. Początkowy wzrost załamuje się, podobnie jak w średniej wszystkich chrztów w latach 1768-1772, po czym wykres wzrasta, by do końca badanego okresu utrzymywać się na poziomie około dwunastu chrztów rocznie.

Interesujące jest to, jak rozkłada się liczba chrztów szlacheckich w poszczególnych wsiach. Blisko połowa wpisów dotyczy Strzebielina i Wyszecina, wsi charakteryzujących się największym rozdrobnieniem własności szlacheckiej. Co ciekawe, podobnie, jedynie z niewielkimi przesunięciami, przedstawia się rozkład małżeństw szlacheckich ${ }^{38}$.

${ }^{35}$ Uwzględniono te wpisy, w których ojciec bądź matka dziecka zostali określeni jako szlachta, oraz te, które, mimo braku adnotacji „nobilis”, wskutek wcześniej przeprowadzonej kwerendy nie pozostawiały wątpliwości co do szlacheckiego rodowodu przynajmniej jednego z rodziców dziecka.

${ }^{36}$ A. StachowsKa-KrzyżankowsKa, op.cit., s. 124.

${ }^{37}$ Wszystkie umieszczone w tekście tabele i wykresy opracowano na podstawie tego źródła.

${ }^{38}$ A. StachowsKa-KrzyŻankowsKa, op.cit., s. 122-123, 128-129. 
Wykres 1. Średnia roczna liczby chrztów

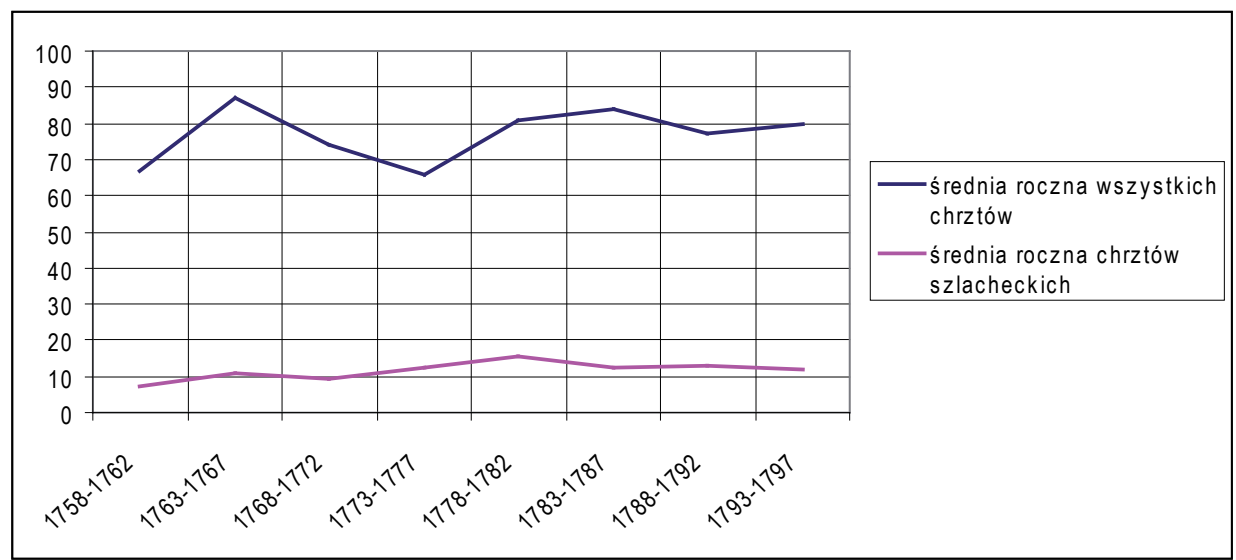

Tabela 2. Liczba chrztów szlacheckich w poszczególnych wsiach

\begin{tabular}{|l|c|}
\hline \multicolumn{1}{|c|}{ Miejscowość } & Liczba chrztów \\
\hline Strzebielino & 124 \\
\hline Wyszecino & 102 \\
\hline Gowino & 55 \\
\hline Milwino & 42 \\
\hline Robakowo & 39 \\
\hline Dąbrówka & 31 \\
\hline Milwińska Huta & 23 \\
\hline Wyszecka Huta & 11 \\
\hline Sosnowa Góra & 8 \\
\hline Bysmark & 5 \\
\hline Częstkowo & 5 \\
\hline Luzino & 4 \\
\hline Barłomino & 3 \\
\hline Tępcz & 3 \\
\hline Barłomińska Huta & 1 \\
\hline Kębłowo & 1 \\
\hline Kębłowski Młyn & 1 \\
\hline Mokry Bór & 1 \\
\hline Paraszyno & 1 \\
\hline Pobłocie & 1 \\
\hline Ustarbowo & 1 \\
\hline
\end{tabular}

\section{SEZONOWOŚĆ URODZEŃ I POCZĘĆ}

Jak pokazuje tabela 3, w parafii luzińskiej najwięcej dzieci przyszło na świat $\mathrm{w}$ marcu. Analizując wszystkie urodzenia, widzimy, że ich szczyt przypada na miesiące zimowe: od grudnia do marca. Dla urodzeń szlacheckich statystyka ta 
jest dość zbliżona. Największe natężenie narodzin przypada tu na okres zimowy i wczesnowiosenny: od stycznia do maja.

Tabela 3. Sezonowość poczęć i urodzeń

\begin{tabular}{|l|r|r|r|r|r|r|r|r|r|r|r|r|}
\hline Miesiąc poczęcia & IV & V & VI & VII & VIII & IX & X & XI & XII & I & II & III \\
\hline Miesiąc urodzenia & I & II & III & IV & V & VI & VII & VIII & IX & X & XI & XII \\
\hline Wszystkie chrzty & 279 & 243 & 302 & 267 & 260 & 248 & 183 & 219 & 243 & 272 & 258 & 301 \\
\hline Chrzty szlacheckie & 42 & 43 & 50 & 38 & 42 & 39 & 31 & 37 & 32 & 27 & 42 & 39 \\
\hline
\end{tabular}

Na tej podstawie możliwe jest także obliczenie sezonowości poczęć, co daje pewien pogląd na aktywność seksualną danej społeczności. Zarówno w przypadku szlachty, jak i ogółu parafian luzińskich najwyższa liczba poczęć przypada na miesiące wiosenne. Mimo rolniczego charakteru społeczności (także tej drobnoszlacheckiej) nie zauważa się znacznego spadku liczby poczęć w miesiącach ciepłych, w których prace polowe wymagają największego zaangażowania. Nie odnotowuje się też większej wstrzemięźliwości w czasie wielkiego postu. Najmniejszą aktywność wykazywano w miesiącach jesienno-zimowych: październiku, listopadzie i grudniu, jednak nie można jednoznacznie stwierdzić, że obniżona liczba poczęć grudniowych związana jest $\mathrm{z}$ czasem adwentu. Zastanawia natomiast pewna rozbieżność między szlachtą a luzińskim chłopstwem. Szlachta najmniejszą aktywność seksualną wykazywała w styczniu, który dla ogółu społeczności plasuje się na wysokim czwartym miejscu. Odwrotnie jest z majem, który w przypadku szlachty charakteryzuje się wysoką liczbą poczęć, a dla całej parafii jest miesiącem obniżonej aktywności.

\section{CZAS I MIEJSCE CHRZTU}

Przepisy prawa kościelnego stanowczo nakazywały, by nowo narodzone dziecko ochrzcić jak najszybciej i by ceremonia ta odbyła się w kościele parafialnym ${ }^{39}$. Wysoka śmiertelność noworodków sprawiała, że rodzice żyjący w nieustannej trosce o przeżycie dziecka starali się je ochrzcić jak najszybciej ${ }^{40}$.

W parafii luzińskiej do 1766 r. zapisywano jedynie datę chrztu. Obliczenie, ile wynosił odstęp pomiędzy narodzinami a chrztem, jest więc możliwe jedynie dla chrztów udzielanych od marca $1766 \mathrm{r}$.

W latach 1766-1797 dzieci chrzczono głównie w pierwszym tygodniu po narodzeniu, przeważnie w drugim lub trzecim dniu życia. Jedynie w czterech przypadkach urodzenie i chrzest dzieliło dziesięć i więcej dni. Jak wynika z poniższej

\footnotetext{
${ }^{39}$ C. Kuklo, op.cit., s. 315-316.

${ }^{40}$ Ibid., s. 317.
} 
tabeli, w jednym przypadku osoba udzielająca chrztu podała, że odbył się on w 32 dni po narodzinach. Po przestudiowaniu kilku metryk poprzedzających to wydarzenie i kilku po nim następujących można założyć, że jest to błąd wpisującego, który jako miesiąc chrztu wpisał grudzień zamiast listopada ${ }^{41}$.

Tabela 4. Liczba dni między urodzeniem a chrztem dzieci w rodzinach szlacheckich parafii Luzino

\begin{tabular}{|c|c|}
\hline $\begin{array}{c}\text { Liczba dni } \\
\text { pomiędzy urodzeniem a chrztem }\end{array}$ & Liczba chrztów \\
\hline 0 & 34 \\
\hline 1 & 95 \\
\hline 2 & 76 \\
\hline 3 & 66 \\
\hline 4 & 43 \\
\hline 5 & 24 \\
\hline 6 & 20 \\
\hline 7 & 17 \\
\hline 8 & 6 \\
\hline 9 & 3 \\
\hline 10 & 1 \\
\hline 11 & 1 \\
\hline 12 & 1 \\
\hline $32^{*}$ & 1 \\
\hline
\end{tabular}

${ }^{*}$ Prawdopodobnie pomyłka pisarska.

Jak podaje C. Kuklo ${ }^{42}$, prawo dopuszczało chrzest poza kościołem jedynie w wyjątkowych wypadkach. Do takich należało zagrożenie życia nowo narodzonego, a także warunki pogodowe uniemożliwiające dotarcie do świątyni. Wszystko wskazuje na to, że szlachta z luzińskiej parafii stosowała się do tych zaleceń kleru. Chrzty, których udzielono poza kościołem, dotyczą jedynie dziewięciu przypadków, w których wystąpiło zagrożenie życia dziecka. Czwórka z tych dzieci przeżyła (w tym jedna para bliźniąt) i ceremonia została dopełniona w kościele.

\section{IMIONA}

Nadanie imienia ściśle wiąże się z obrzędem chrztu świętego i stanowi ważny moment w życiu człowieka. Zachowane libri baptisatorum to źródła, które coraz częściej wykorzystywane są w badaniach nad imiennictwem staropolskim. Analiza metryk umożliwia zbadanie, jakie czynniki miały decydujący wpływ na ochrzczenie dziecka konkretnym imieniem. Na wybór imienia chrzestnego wpływały panująca moda, tradycja rodzinna, wymagania narzucane przez środowisko,

${ }^{41}$ Jeśli tak było w rzeczywistości, to narodziny i chrzest dzieliły jedynie 2 dni.

${ }^{42}$ Chrzest Jana Andrzeja Lewińskiego, syna Antoniego i Teresy z Frezów, źródło: AAG, Parafia katolicka w Luzinie, sygn. W905, k. 68v. 
a przede wszystkim indywidualne upodobania rodziców ${ }^{43}$. Nie można również bagatelizować wpływu Kościoła.

Ustawodawstwo kościelne wymagało od duchownych, by nowo narodzone dzieci chrzcili wyłącznie imionami chrześcijańskimi. Doprowadziło to z czasem do prawie całkowitego zaniku imion słowiańskich na rzecz imion upamiętniających świętych i błogosławionych ${ }^{44}$.

Wśród szlachty luzińskiej najpopularniejszymi imionami męskimi nadawanymi dzieciom w drugiej połowie XVIII w. były Jan, Michał i Józef. Popularność antroponimu Jan zauważalna była już w XVII stuleciu ${ }^{45}$. Wzrost zainteresowania imieniem Józef należy wiązać $\mathrm{z}$ intensyfikującym się kultem maryjnym ${ }^{46}$. Jak podaje Krzysztof Mikulski, w XVIII w. nastąpił intensywny powrót do kultu św. św. Antoniego i Wincentego, a starsze antroponimy, jak np. Jan, otrzymały nowych patronów (np. Jan Nepomucen). Wzrosła również popularność takich imion, jak Franciszek czy Antoni ${ }^{47}$. Jak pokazuje tabela 5, powyższe ustalenia znajdują też swoje potwierdzenie $\mathrm{w}$ parafii luzińskiej. W czołówce popularnych imion ciągle też utrzymywał się Wojciech.

Tabela 5. Najpopularniejsze imiona nadawane dzieciom szlacheckim w parafii Luzino $\mathrm{w}$ drugiej połowie XVIII w..$^{48}$

\begin{tabular}{|l|c|l|c|}
\hline Imię żeńskie & Liczba nominacji & Imię męskie & Liczba nominacji \\
\hline Marianna & 56 & Jan & 38 \\
\hline Anna & 37 & Michał & 28 \\
\hline Dorota & 20 & Józef & 27 \\
\hline Barbara & 17 & Antoni & 24 \\
\hline Konstancja & 15 & Franciszek & 18 \\
\hline Franciszka & 14 & Wojciech & 15 \\
\hline Katarzyna & 13 & Jakub & 12 \\
\hline Teresa & 13 & Adam & 6 \\
\hline Joanna & 6 & Aleksander & 5 \\
\hline Józefina & 7 & Ignacy & 3 \\
\hline
\end{tabular}

${ }^{43}$ Marek GóRnY, Wybór imion chrzestnych dla dzieci szlacheckich w powiecie kcyńskim $w$ XVII wieku, Genealogia. Studia i materiały historyczne, t. 5: 1995, s. 54.

${ }^{44}$ Ibid.

${ }^{45}$ Ibid., s. 63; Krzysztof Mikulski, Rodzinne mikroświaty w nurcie życia miejskiego Polski przedrozbiorowej (Mody onomastyczne wśród mieszczan miast polskich na przykładzie Torunia w XVI-XVIII wieku), [in:] Rodzina, gospodarstwo domowe i pokrewieństwo na ziemiach polskich w perspektywie historycznej - ciagłość czy zmiana?, red. Cezary KukLo, Warszawa 2013, s. 154-157; Janusz Hochleitner, Sakrament chrztu na Warmii w potrydenckiej liturgii i zwyczajach, Studia Warmińskie, t. 29: 2002, s. 290-291.

${ }^{46}$ K. Mikulski, Rodzinne mikroświaty, s. 158.

${ }^{47}$ Ibid.

${ }^{48} \mathrm{~W}$ tabeli uwzględniono jedynie imiona pierwsze. Uwzględniając także imiona drugie i trzecie, kolejność przedstawia się następująco: imiona męskie: Jan, Józef, Antoni, Michał i Wojciech; imiona kobiece: Marianna, Anna, Dorota, Konstancja i Barbara. 
Wśród antroponimów żeńskich na czoło zdecydowanie wybija się imię Marianna, której popularność związana jest podobnie jak w przypadku Józefa $\mathrm{z}$ kultem Najświętszej Marii Panny ${ }^{49}$. Inne imiona nadawane często szlacheckim córkom to Anna, Dorota, Barbara, Konstancja, Franciszka i Katarzyna.

W społeczności katolickiej dawnej Polski na dobór imion chrzestnych wpływ miał kalendarz. Często dzieci otrzymywały imiona patrona, którego święto przypadało w okolicy dnia narodzin ${ }^{50}$. Nie wydaje się to zasadne w przypadku szlachty parafii luzińskiej. Ze względu na liczne święta maryjne dla imienia Marianna nie sposób dokładnie stwierdzić wpływu kalendarza na nadawanie tego imienia nowo narodzonym dziewczynkom. Nie wydaje się mieć to jednak wielkiego znaczenia, gdyż analiza wykazała, że liczba nadań tego imienia w poszczególnych miesiącach roku waha się na podobnym poziomie, to jest od 5 do 8 chrztów miesięcznie. Nieco inaczej jest w przypadku imienia Jan, gdyż najwięcej nadań tego imienia odnotowano w czerwcu i grudniu, na które to miesiące przypadają wspomnienia św. Jana Chrzciciela i św. Jana Ewangelisty. W pozostałych przypadkach jedynie sporadycznie można wychwycić oddziaływanie kalendarza na nadawane przez szlachtę imiona.

Znacznie ciekawiej przedstawia się wpływ imion osób z najbliższego otoczenia chrzestnięcia. Zdecydowałam się porównać imiona chrzczonych dzieci z imionami ich rodziców i rodziców chrzestnych. Okazało się, że na 462 chrzty aż w 184 przypadkach jedno lub więcej imion dziecka pokrywało się z imieniem rodzica bądź rodzica chrzestnego. 30 chłopców otrzymało imię ojca, a u czterech to imię wystąpiło jako drugie. Aż 50 chłopców ochrzczono imieniem ojca chrzestnego, a pięciu nadano zarówno imię ojca, jak i imię chrzestnego. Podobne wyniki otrzymano w przypadku dziewczynek. $31 \mathrm{z}$ nich odziedziczyło imię po matce rodzonej, a aż 62 po matce chrzestnej. 12 dziewczynek ochrzczono zarówno imieniem matki rodzonej, jak i chrzestnej. Być może też Joanna Józefina Ustarbowska i Konstancja Józefina Skwarcz odziedziczyły imiona po swych ojcach: Janie Ustarbowskim i Józefie Skwarczu.

Nadawanie dzieciom więcej niż jednego imienia początkowo charakteryzowało głównie znamienitszą szlachtę i magnaterię, odzwierciedlając w ten sposób wysoką pozycję społeczną danej rodziny. Z czasem jednak ta przybyła z zachodu moda rozpowszechniła się i pod koniec XVIII w. nadawanie dzieciom więcej niż jednego imienia stało się dość powszechne. Drobna szlachta kaszubska, która niejednokrotnie stanem posiadania równała się z okolicznym chłopstwem, w większości chrzciła potomstwo jednym imieniem (260 chrztów). 196 dzieci otrzymało na chrzcie dwa imiona. Trzema imionami ochrzczono jedynie czwórkę dzieci, jednego chłopca, Antoniego Wojciecha Józefa Bychowskiego, syna Franciszka i Anny, i trzy dziewczynki: Katarzynę Mariannę Józefinę Dzięcielską, córkę Michała i Ma-

\footnotetext{
${ }^{49}$ K. Mikulski, Rodzinna mikroświaty, s. 162.

${ }^{50}$ Ibid., s. 165; M. GóRNY, op.cit., s. 64.
} 
rianny, Konstancję Mariannę Annę Pobłocką, córkę Michała i Doroty, i Mariannę Barbarę Teresę Frezę, córkę Michała i Petroneli.

Najpopularniejsze wśród luzińskiej szlachty podwójne zestawy imion to Jan Antoni (5 razy), Jan Jakub (4 razy) Jan Andrzej (3 razy). U dziewczynek takie zestawy ograniczają się do dwóch-trzech wystąpień. Najwięcej, bo 3 razy pojawia się Konstancja Marianna. Jest też szereg podwójnych imion występujących jedynie dwa razy, np. Marianna Anna, Marianna Konstancja czy Anna Katarzyna. Jak zauważa K. Mikulski, zestawy antroponimów męskich zazwyczaj tworzyły imiona, które łączyła bliskość dni, w których obchodzono wspomnienie odpowiadających im patronów, jak wspomniany Jan Antoni. Natomiast popularność zestawu Jan Jakub może sugerować żywe wpływy luterańskie ${ }^{51}$. Podwójne antroponimy żeńskie tworzono zazwyczaj, łącząc ze sobą najpopularniejsze imiona ${ }^{52}$, co również znajduje odzwierciedlenie w omawianych metrykach szlacheckich.

\section{RODZICE CHRZESTNI}

Rodziców chrzestnych wybierano dzieciom bardzo starannie. Mieli oni dbać o duchowe dobro dzieci, a w razie konieczności przejąć obowiązki rodziców wobec dziecka. Wierzono także, że dziecko dziedziczy po chrzestnych pewne cechy charakteru i zaciąga z nimi powinowactwo duchowe, co m.in. wykluczało możliwość zawarcia małżeństwa między rodzicem chrzestnym a chrzestnięciem ${ }^{53}$.

Podczas chrztów szlacheckich w luzińskiej parafii nigdy nie występowało więcej niż dwoje chrzestnych: jeden mężczyzna i jedna kobieta. Dwa razy wymieniono tylko jednego chrzestnego. Chrzestną Józefa, syna Jakuba i Konstancji Dąbrowskich, była Konstancja Licowa ${ }^{54}$, Franciszka Jakuba, syna Franciszka i Katarzyny Wyszeckich, Magdalena Bychowska z Tępcza. O ile w pierwszym wypadku najprawdopodobniej chodzi o chrzest $\mathrm{z}$ wody dokonany przez akuszerkę, o tyle przy drugim dziecku nie ma informacji mogących wyjaśnić obecność przy chrzcie tylko jednego chrzestnego.

Szlachta zazwyczaj wybierała na rodziców chrzestnych osoby z własnego kręgu rodzinnego lub z najbliższego sąsiedztwa. Przeważnie były to osoby nobilitowane, choć bardzo często na chrzestnych brano także swych sąsiadów niemających szlacheckich korzeni. Spośród 41 wpisów, gdzie oboje chrzestni nie należeli do szlachty, dziewięć dotyczy rodziny Albeckich, która w drugiej połowie XVIII w. sporadycz-

${ }^{51}$ K. MiKulski, Rodzinne mikroświaty, s. 171.

${ }^{52}$ Ibid.

${ }^{53}$ K. Korenda, Chrzty w parafii Pszczew, s. 77.

${ }^{54}$ Konstancja Licowa była najprawdopodobniej akuszerką, która odebrała poród. Co ciekawe, nie ma jej na liście kobiet uprawnionych do pomocy rodzącym. Lista taka, sporządzona ręką proboszcza Prądzyńskiego, znajduje się na pierwszej stronie księgi chrztów. Początkowo wymienione są trzy akuszerki: Katarzyna Zęplowa Brunowa z Barłomina, Regina Krużowa z Luzina i Magdalena Cuperka z Gowina Dalszego. Pod datą 1772 dopisane są kolejne: Katarzyna Kleynowa ze Strzebielina, Anna Ptachowa z Barłomina, Marianna Tworzka z Kębłowa i Krystyna Pręczkowa z Robakowa. 
nie występowała z dopiskiem „nobilis” ${ }^{55}$. W 111 przypadkach przynajmniej jedno $\mathrm{z}$ chrzestnych nie należało do warstwy szlacheckiej. W mniejszym lub większym stopniu nienobilitowani chrzestni pojawiali się przy chrztach prawie każdej rodziny drobnoszlacheckiej zamieszkującej parafię luzińską w drugiej połowie XVIII w. Wyjątkiem jest tu jedynie ród Bychowskich, u których na 30 chrztów nie odnotowano ani jednego chrzestnego wywodzącego się z niższej warstwy społecznej.

Dwukrotnie chrzestnym był proboszcz, Grzegorz Plutowski, i raz wikary Michał Józef Goślicki.

Najczęściej jako chrzestni występowali przedstawiciele rodu Zelewskich (71 razy jako matki chrzestne i 52 razy jako ojcowie chrzestni), a także Tępscy (38 razy jako matki chrzestne, 36 razy jako ojcowie chrzestni), Wyszeccy (31 matek i 34 ojców chrzestnych) i Mach Milwińscy (27 matek i 35 ojców).

\section{UWAGI KOŃCOWE}

W drugiej połowie XVIII w. w parafii luzińskiej ochrzczono 462 dzieci szlacheckich (260 dziewczynek i 202 chłopców). Najliczniej reprezentowane są tu rodziny Zelewskich (33 chrzty), Tępskich (31 chrztów), Bychowskich (30 chrztów), Dąbrowskich (30 chrztów) oraz Gowińskich ( 28 chrztów) i Wyszeckich ( 28 chrztów). Najliczniejszego potomstwa dochował się Antoni Pobłocki, któremu w przeciągu dwudziestu lat (1763-1783), z jednej małżonki, Marianny z Gowińskich urodziło się 16 dzieci. Dziesięciorga dzieci dorobili się Jan Tempski i Teresa z Wyszeckich oraz Michał Tempski i Marianna z Kaszewskich. Dziewięcioro dzieci urodziła Marianna Mach Milwińska swemu prawowitemu małżonkowi, Maciejowi Wilkowskiemu, a ośmioro potomstwa mieli Wojciech i Marianna z Dąbrowskich Szemierowscy oraz Michał i Katarzyna z Machów Milwińskich Studzińscy. W sześciu przypadkach dziecko urodziło się martwe lub zmarło zaraz po urodzeniu, co skrupulatnie odnotowano w księdze chrztów.

Panny szlachcianki powiły sześcioro dzieci nieślubnych (trzy dziewczynki i trzech chłopców), każda z nich urodziła tylko jedno dziecko z nieprawego łoża. Pięć z tych chrztów odbyło się w latach 1779-1782. W analizowanym źródle odnaleziono tylko jeden chrzest nieślubnego dziecka, którego ojciec wywodził się ze szlachty. Dotyczyło to chrzcin Wojciecha, syna Jana Albeckiego i Katarzyny Ptakówny, jednak należy nadmienić, że przy Albeckim nie było już wtedy określenia „nobilis”.

Praca ta nie rości sobie praw do pełnego wyczerpania tematu. Prezentowane tu spostrzeżenia są kolejnym etapem badań nad kaszubską rodziną drobnoszlachecką w okresie staropolskim. Niezbędne jest w tej chwili przeprowadzenie kwerendy i opracowanie metryk zawartych w luzińskiej księdze zgonów z drugiej połowy XVIII w. Uzyskane w ten sposób dane i ich szczegółowa analiza dadzą pogląd na poziom umieralności dzieci i niemowląt $\mathrm{w}$ badanym okresie, pozwolą na wychwycenie i przebadanie rodzin zamkniętych i znacznie ułatwią prace nad rekonstrukcją rodzin drobnoszlacheckich $\mathrm{w}$ dawnym powiecie puckim i mirachowskim.

${ }^{55}$ A. STAChowsKa-KrzyŻankowsKa, op.cit., s. 130. 
Tabela 6. Wykaz dzieci szlacheckich ochrzczonych w Luzinie w latach 1758-1797 (w wykazie zastosowano źródłową formę pisowni imion i nazwisk)

\begin{tabular}{|c|c|c|c|c|c|}
\hline Rok & Imię dziecka & Nazwisko ojca & Imię ojca & $\begin{array}{c}\text { Nazwisko } \\
\text { rodowe matki }\end{array}$ & Imię matki \\
\hline 1758 & Constantia Josephina & Skwarcz & Josephus & - & Barbara \\
\hline 1758 & Franciscus Bartholomaeus & Węsierski & Martinus & - & Catharina \\
\hline 1758 & Carolus Reinaldus & Gromkowski & Georgius & - & Dorothea \\
\hline 1758 & Victoria & Melesicki & Christianus & - & Barbara \\
\hline 1758 & Catharina Susanna & Lewiński & Ludovicus & - & Ludovica \\
\hline 1759 & Catharina Veronca & Zelewski & Andreas & - & Marianna \\
\hline 1759 & Joannes Jacobus & Freza & Adalbertus & - & Susanna \\
\hline 1759 & $\begin{array}{l}\text { Catharina Marianna } \\
\text { Josephina }\end{array}$ & Dzięcielski & Michael & - & Marianna \\
\hline 1759 & Barbara Joanna & Wyszecki & Michael & - & Anna \\
\hline 1759 & Alexander & Wyszecki & Joannes & - & Marianna \\
\hline 1759 & Catharina Elizabetha & Mach & Ernestus & - & Marianna \\
\hline 1759 & Marianna Dorothea & Chmieliński & Joannes & - & Teressia \\
\hline 1760 & Constantia Hedviga & Bychowski & Franciscus & - & Anna \\
\hline 1760 & Heva Marianna & Bychowski & Michael & - & Marianna \\
\hline 1760 & Marianna Rosalia & Wyszecki & Adalbertus & - & Anna \\
\hline 1760 & Anna & Sychowski & Adalbertus & - & Anna \\
\hline 1760 & Jacobus & Albecki & Adalbertus & - & Marianna \\
\hline 1760 & \begin{tabular}{|l|} 
Dorothea \\
\end{tabular} & Swichowski & Georgius & - & Bogumila \\
\hline 1760 & Constantia Marianna & Dąbrowski & Jacobus & 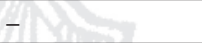 & Catharina \\
\hline 1760 & Dorothea & Zelewski & Jacobus & - & Constantia \\
\hline 1760 & Eva Konstantia & Gowiński & Jacobus & - & Apollonia \\
\hline 1760 & Barbara Ludovica & Mach & Joannes & - & Konstantia \\
\hline 1761 & Catharina & Węsierski & Martinus & - & Catharina \\
\hline 1761 & Marianna & Paraski & Ernest & - & Teressia \\
\hline 1761 & Catharina & Dziencelski & Michael & - & Marianna \\
\hline 1761 & Leonora & Albecki & Josephus & - & Constantia \\
\hline 1761 & Antonius & Gowiński & Adam & - & Marianna \\
\hline 1761 & Constantia & Małotka & Alexander & - & Constantia \\
\hline 1762 & Teresa & Mach & Ernest & - & Marianna \\
\hline 1762 & Marianna Magdalena & Bychowski & Franciscus & - & Anna \\
\hline 1762 & Josephus & Lewiński & Ludovicus & - & Ludovica \\
\hline 1762 & Adalbertus & Wiszecki & Adalbertus & - & Teresa \\
\hline 1762 & Marianna & Dąbrowski & Jacobus & - & Eva \\
\hline 1762 & Eva & Skwarcz & Josephus & - & Barbara \\
\hline 1762 & Marianna & Pobłocki & Michael & - & Constantia \\
\hline 1762 & Marianna & Kos & Michael & - & Barbara \\
\hline 1762 & Concordia & Gowiński & Michael & - & Anna \\
\hline 1763 & Michael & Albecki & Adalbertus & - & Marianna \\
\hline
\end{tabular}




\begin{tabular}{|c|c|c|c|c|c|}
\hline Rok & Imię dziecka & Nazwisko ojca & Imię ojca & $\begin{array}{c}\text { Nazwisko } \\
\text { rodowe matki }\end{array}$ & Imię matki \\
\hline 1763 & Josephus & Wyszecki & Adalbertus & - & Anna \\
\hline 1763 & Susanna & Pobłocki & Antonius & - & Marianna \\
\hline 1763 & Catharina Marianna & Gowiński & Jacobus & - & Apollonia \\
\hline 1763 & Antonius Felicianus & Wyszecki & Jacobus & - & Victoria \\
\hline 1763 & Anna & nieślubne & nieślubne & Tempska & Anna \\
\hline 1763 & Antonius & Wyszecki & Joannes & - & Marianna \\
\hline 1763 & Antonius & Albecki & Josephus & - & Constantia \\
\hline 1763 & Anna & Dombrowski & Jacobus & - & Eva \\
\hline 1763 & Marianna & Dombrowski & Jacobus & - & Constantia \\
\hline 1763 & Constantia & Albecki & Chrystianus & - & Marianna \\
\hline 1763 & Dorothea & Bychowski & Michael & - & Florianna \\
\hline 1764 & Theresia & Pobłocki & Antonius & - & Marianna \\
\hline 1764 & Eva Constantia & Malotka & Jacobus & - & Alexandra \\
\hline 1764 & Dorothea & Delk & Michael & - & Christina \\
\hline 1764 & Rosalia & Węsierski & Joannes & - & Constantia \\
\hline 1764 & Michael & Freza & Adalbertus & - & Susanna \\
\hline 1764 & Francisca & Gowiński & Adam & - & Anna \\
\hline 1764 & Martinus Florianus & Chmieliński & Joannes & - & Teressia \\
\hline 1764 & Joannes Jacobus & Szemierowski & Adalbertus & - & Marianna \\
\hline 1764 & Adamus Nicolaus & Dombrowski & Jacobus & - & Constantia \\
\hline 1764 & Joannes Joachimus & Sychowski & \begin{tabular}{|l|} 
Joannes \\
Georgius \\
\end{tabular} & - & Bogumilla \\
\hline 1765 & Franciscus & Koss & Michael & - & Barbara \\
\hline 1765 & Dorothea & Gowiński & Jacobus & 28 & Apollonia \\
\hline 1765 & Michael & Dąbrowski & Joannes & - & Catharina \\
\hline 1765 & Antonius Michael & Wyszecki & Adalbertus & - & Anna \\
\hline 1765 & Josephus & Gowiński & Michael & - & Anna \\
\hline 1765 & Michael & Zelewski & Andreas & - & Marianna \\
\hline 1765 & Adamus Ernestus & Węsierski & Martinus & - & Catharina \\
\hline 1765 & Andreas Chrisogonus & Koss & Michael & - & Magdalena \\
\hline 1765 & Zuzanna & Bichowski & Michael & - & Florentina \\
\hline 1766 & Joannes Antonius & Pobłocki & Antonius & - & Marianna \\
\hline 1766 & Concordia & Lewiński & Ludovicus & - & Ludovica \\
\hline 1766 & Josephus & Wyszecki & Joannes & - & Marianna \\
\hline 1766 & Georgius Leopoldus & Grąbkowski & Carolus & - & Joanna \\
\hline 1766 & Josephus & Albecki & Josephus & - & Constantia \\
\hline 1766 & $\begin{array}{l}\text { Antonius Adalbertus } \\
\text { Josephus }\end{array}$ & Bychowski & Franciscus & - & Anna \\
\hline 1766 & Jacobus & Pudkamer & Michael & - & Ludovica \\
\hline 1766 & Stanislaus & Dąbrowski & Jacobus & - & Eva \\
\hline 1766 & Adalbertus Laurentius & Wyszecki & Jacobus & - & Victoria \\
\hline
\end{tabular}




\begin{tabular}{|c|c|c|c|c|c|}
\hline Rok & Imię dziecka & Nazwisko ojca & Imię ojca & $\begin{array}{c}\text { Nazwisko } \\
\text { rodowe matki }\end{array}$ & Imię matki \\
\hline 1766 & Ludovica Victoria & Zelewski & Jacobus & - & Anna \\
\hline 1766 & Andreas Josephus & Sichowski & Joannes & - & Marianna \\
\hline 1766 & Dorothea & Albecki & Adalbertus & - & Marianna \\
\hline 1767 & Melchior & Pobłocki & Antonius & - & Marianna \\
\hline 1767 & Joannes Ernestus & Grąbkowski & Carolus & - & Joanna \\
\hline 1767 & Michael & Chosznicki & Christianus & - & Marianna \\
\hline 1767 & Josephus Casimirus & Malotka & Jacobus & - & Alexandra \\
\hline 1767 & Joanna Josephina & Ustarbowski & Joannes & - & Catharina \\
\hline 1767 & Josephus Gregorius & Gowiński & Jacobus & - & Apollonia \\
\hline 1767 & Josephus & Kos & Michael & - & Barbara \\
\hline 1767 & Dorothea & Dąbrowski & Jacobus & - & Constantia \\
\hline 1767 & Anna Francisca & Chmieliński & Joannes & - & Theresia \\
\hline 1767 & Franciscus & Albecki & Josephus & - & Constantia \\
\hline 1767 & Joannes Josephus & Szymirowski & Adalbertus & - & Marianna \\
\hline 1768 & Antonius & Tępski & Jacobus & - & Anna \\
\hline 1768 & Adamus & Zelewski & Michael & - & Eleonora \\
\hline 1768 & Christina & Delk & Michael & - & Christina \\
\hline 1768 & Adalbertus & Zelewski & Andreas & - & Marianna \\
\hline 1768 & Josephus Adalbertus & Tępski & Joannes & - & Theresia \\
\hline 1768 & Concordia Joanna & Wyszecki & Adalbertus & - & Anna \\
\hline 1768 & Marianna Euphemia & Pobłocki & Antonius & - & Marianna \\
\hline 1768 & Marianna Catharina & Gowiński & Michael & 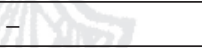 & Marianna \\
\hline 1769 & Michael Ernestus & Bychowski & Franciscus & & Anna \\
\hline 1769 & Barbara Zophia & Bychowski & Michael & $-\quad-200$ & Catharina \\
\hline 1769 & Melchior Balthasar & Mauszycki & Mathias & - & Constantia \\
\hline 1769 & Stanislaus & Zielewski & Jacobus & - & Anna \\
\hline 1769 & Adalbertus Vincentius & Wyszecki & Joannes & - & Marianna \\
\hline 1769 & Marianna & Albecki & Adalbertus & - & Marianna \\
\hline 1769 & Joannes & Rhoda & Martinus & Lewińska & Marianna \\
\hline 1769 & Antonius & Szemirowski & Adalbertus & - & Marianna \\
\hline 1769 & Marianna & Zelewski & Michael & - & Eleonora \\
\hline 1769 & Elisabeth Scholastica & Gowiński & Jacobus & - & Apollonia \\
\hline 1769 & Michael Andreas & Gowiński & Jacobus & - & Apollonia \\
\hline 1769 & Christianus & Gruba & Michael & - & Constantia \\
\hline 1770 & Adalbertus Antonius & Robakowski & Joannes & - & Catharina \\
\hline 1770 & Adalbertus & Kos & Michael & - & Elisabetha \\
\hline 1770 & Marianna Joanna & Mauszycki & Mathias & - & Constantia \\
\hline 1770 & Theressia & Tępski & Jacobus & - & Anna \\
\hline 1770 & Jacobus Josephus & Dąbrowski & Jacobus & - & Constantia \\
\hline 1770 & Barbara Rosalia & Pobłocki & Antonius & - & Marianna \\
\hline 1770 & Dorothea Theresia & Chmieliński & Joannes & - & Theresia \\
\hline
\end{tabular}




\begin{tabular}{|c|c|c|c|c|c|}
\hline Rok & Imię dziecka & Nazwisko ojca & Imię ojca & $\begin{array}{c}\text { Nazwisko } \\
\text { rodowe matki }\end{array}$ & Imię matki \\
\hline 1771 & Apollonia Brigida & Bychowski & Joannes & - & Theresia \\
\hline 1771 & Anna & Zelewski & Michael & - & Anna \\
\hline 1771 & Anna & Mach & Jacobus & - & Ludovica \\
\hline 1771 & Mathias Ignatius & Tokarski & Jacobus & - & Anna \\
\hline 1771 & Catharina & Dąbrowski & Jacobus & - & Ludovica \\
\hline 1771 & Antonius Benedictus & Tępski & Joannes & - & Theresia \\
\hline 1771 & Anna & Wyszecki & Adalbertus & - & Anna \\
\hline 1771 & Michael Laurentius & Pobłocki & Antonius & - & Marianna \\
\hline 1771 & Eleonora & Bychowski & Franciscus & - & Anna \\
\hline 1771 & Antonius & Mach & Michael & - & Eva \\
\hline 1771 & Michael & Zelewski & Jacobus & - & Anna \\
\hline 1771 & Joannes Andreas & Szemirowski & Adalbertus & - & Marianna \\
\hline 1771 & Joannes Jacobus & Tępski & Michael & - & Marianna \\
\hline 1772 & Anna Scholastica & Bychowski & Michael & - & $\begin{array}{l}\text { Catharina } \\
\text { Florianna }\end{array}$ \\
\hline 1772 & Marianna Aleandra & Zelewski & Michael & - & Ludovica \\
\hline 1772 & Anna & Gowiński & Michael & - & Anna \\
\hline 1772 & Marianna & Sychowski & Franciscus & - & Marianna \\
\hline 1772 & Dorothea & Mauszycki & Mathias & - & Constantia \\
\hline 1772 & Antonius Josephus & Robakowski & Joannes & - & Catharina \\
\hline 1773 & Eleonora Eva & Szemirowski & Adalbertus & - & Marianna \\
\hline 1773 & Anna & Malotka & Adalbertus & - & Alexandra \\
\hline 1773 & Antonius Stanislaus & Pobłocki & Antonius & 0 & Marianna \\
\hline 1773 & Anna & Sychowski & Joannes & - & Marianna \\
\hline 1773 & Joannes & Zelewski & Jacobus & - & Anna \\
\hline 1773 & Jacobus & Welckowski & Mathias & - & Marianna \\
\hline 1773 & Joachim Joannes & Tępski & Joannes & - & Theresia \\
\hline 1773 & Josephus & Dąbrowski & Jacobus & - & Constantia \\
\hline 1773 & Rosalia Constantia & Malotka & Michael & - & Marianna \\
\hline 1773 & Martinus & Dąbrowski & Jacobus & - & Ludovica \\
\hline 1774 & Lucas Franciscus & Bychowski & Franciscus & - & Anna \\
\hline 1774 & Josephina Concordia & Tępski & Adalbertus & - & Concordia \\
\hline 1774 & Jacobus & Kos & Michael & - & Barbara \\
\hline 1774 & Catharina Philippina & Tępski & Michael & - & Marianna \\
\hline 1774 & Marianna & Robakowski & Joannes & - & Catharina \\
\hline 1774 & Joannes Petrus & Kos & Michael & Zelewska & Joanna \\
\hline 1774 & Concordia Eva & Gowiński & Jacobus & Tempska & Apollonia \\
\hline 1774 & Marianna Elisabetha & Bychowski & Michael & Paraska & $\begin{array}{l}\text { Catharina } \\
\text { Florianna }\end{array}$ \\
\hline 1774 & Joannes Bartholomaeus & Gowiński & Joannes & Tempska & Victoria \\
\hline 1774 & Anna & Tokarski & Jacobus & Zelewska & Anna \\
\hline 1774 & Adalbertus Thomas & Wyszecki & Adalbertus & Pałubicka & Anna \\
\hline
\end{tabular}




\begin{tabular}{|c|c|c|c|c|c|}
\hline Rok & Imię dziecka & Nazwisko ojca & Imię ojca & $\begin{array}{c}\text { Nazwisko } \\
\text { rodowe matki }\end{array}$ & Imię matki \\
\hline 1774 & Joannes Andreas & Sychowski & Joannes & Pobłocka & Dorothea \\
\hline 1774 & Barbara Elisabetha & Zelewski & Michael & Warzewska & Marianna \\
\hline 1774 & Michael & Słuszewski & Jacobus & Zelewska & Ludovica \\
\hline 1774 & Josephus & Szarpski & Joannes & Borkowa & Marianna \\
\hline 1774 & Joannes Andreas & Lewiński & Antonius & Frezowa & Theresia \\
\hline 1775 & Anna Victoria & Pobłocki & Antonius & Gowińska & Marianna \\
\hline 1775 & Michael & Zelewski & Antonius & Zelewska & Susanna \\
\hline 1775 & Josephus & Dąbrowski & Jacobus & Gowińska & Constantia \\
\hline 1775 & Constantia & Dąbrowski & Jacobus & Gowińska & Constantia \\
\hline 1775 & Antonius & Gowiński & Michael & Łebińska & Anna \\
\hline 1775 & Michael & Mach & Michael & Miszewska & Eva \\
\hline 1775 & Josephus Laurentius & Lewiński & Jacobus & Jarkowa & Christina \\
\hline 1775 & Theresia Ursula & Bychowski & Franciscus & Częstkowska & Anna \\
\hline 1776 & Apollonia Scholastica & Kos & Michael & Zelewska & Joanna \\
\hline 1776 & Josephus Mathias & Pobłocki & Antonius & Gowińska & Marianna \\
\hline 1776 & Eleonora Eva & Dąbrowski & Joannes & Gowińska & Eva \\
\hline 1776 & franciscus Michael & Welckowski & Mathias & Machowa & Marianna \\
\hline 1776 & Barbara & Mauszycki & Mathias & Robakowska & Constantia \\
\hline 1776 & Marianna & Tokarski & Jacobus & Zelewska & Anna \\
\hline 1776 & Joannes & Ebel & Adalbertus & Mauszycka & Ludovica \\
\hline 1776 & Joannes Aurelianus & Tempski & Jacobus & Dobrzewińska & Anna \\
\hline 1776 & Marianna Paulina & Tempski & Jacobus & Dobrzewińska & Anna \\
\hline 1776 & Michael & Szemierowski & Adalbertus & Dąbrowska & Marianna \\
\hline 1776 & Antonius & Tempski & Adalbertus & Wyszecka & Concordia \\
\hline 1776 & Anna Augustina & Tempski & Joannes & Wyszecka & Theresia \\
\hline 1776 & Marianna & Orent & Michael & Zelewska & Dorothea \\
\hline 1776 & Catharina & Zelewski & Jacobus & Tempska & Anna \\
\hline 1776 & Alexandra & Malotka & Michael & Kozłowska & Marianna \\
\hline 1776 & Francisca Catharina & Bychowski & Michael & Paraska & Catharina \\
\hline 1776 & Apollonia & Malotka & Adalbertus & Słuszewska & Alexandra \\
\hline 1776 & Victoria Marianna & Sychowski & Joannes & Pobłocka & Dorothea \\
\hline 1776 & Dorothea & Dobrzewiński & Jacobus & Lewińska & Ursula \\
\hline 1777 & Aldegundis & Robakowski & Joannes & Ustarbowska & Catharina \\
\hline 1777 & Alexander Mathias & Gowiński & Joannes & Tempska & Victoria \\
\hline 1777 & Josephus & Sychowski & Franciscus & Lewińska & Marianna \\
\hline 1777 & Francisca Barbara & Pobłocki & Antonius & Gowińska & Marianna \\
\hline 1777 & Francisca & Tempski & Michael & Kaszewska & Marianna \\
\hline 1777 & Barbara Apollonia & Kos & Michael & Mauszycka & Elisabetha \\
\hline 1777 & Elisabetha Anna & Mach & Michael & Miszewska & Eva \\
\hline 1777 & Michael Hyiacinthus & Zelewski & Michael & Zelewska & Ludovica \\
\hline 1777 & Anna Constantia & Zelewski & Antonius & Zelewska & Susanna \\
\hline
\end{tabular}




\begin{tabular}{|c|c|c|c|c|c|}
\hline Rok & Imię dziecka & Nazwisko ojca & Imię ojca & $\begin{array}{c}\text { Nazwisko } \\
\text { rodowe matki }\end{array}$ & Imię matki \\
\hline 1778 & Marianna Apollonia & Sychowski & Joannes & Pobłocka & Dorothea \\
\hline 1778 & Josephus Thomas & Gowiński & Joannes & Tempska & Victoria \\
\hline 1778 & Alexander & Bychowski & Adalbertus & Gowińska & Victoria \\
\hline 1778 & Joannes Augustinus & Tempski & Adalbertus & Wyszecka & Concordia \\
\hline 1778 & Barbara Helena & Tempski & Joannes & Wyszecka & Theresia \\
\hline 1778 & Franciscus & Ebel & Adalbertus & Mauszycka & Ludovica \\
\hline 1778 & Joannes Antonius & Mauszycki & Mathias & Robakowska & Constantia \\
\hline 1778 & Joannes Caietans & Wyszecki & Franciscus & Słuszewska & Catharina \\
\hline 1778 & Barbara Marianna & Pobłocki & Antonius & Gowińska & Marianna \\
\hline 1778 & Anna Catharina & Dąbrowski & Joannes & Gowińska & Eva \\
\hline 1778 & Joannes & Welckowski & Mathias & Machowna & Marianna \\
\hline 1778 & Barbara & Dobrzewiński & Jacobus & Lewińska & Ursula \\
\hline 1778 & Joannes Thomas & Zelewski & Joannes & Warzewska & Barbara \\
\hline 1778 & Constantia Ludovica & Robakowski & Joannes & Ustarbowska & Catharina \\
\hline 1779 & Antonius Adamus & Lewiński & Antonius & Frezowna & Theresia \\
\hline 1779 & Marianna Eva & Studziński & Michael & Machowna & Catharina \\
\hline 1779 & Michael Petrus & Malotka & Michael & Kozłowska & Marianna \\
\hline 1779 & Antonius Simon & Malotka & Michael & Kozłowska & Marianna \\
\hline 1779 & Christina & Tokarski & Jacobus & Zelewska & Anna \\
\hline 1779 & Anna Marianna & Lewiński & Jacobus & Jarkowna & Christina \\
\hline 1779 & Adalbertus & Malotka & Adalbertus & Machowna & Alexandra \\
\hline 1779 & Joannes Nepomucenus & Zelewski & Michael & Albrechtowna & Helena \\
\hline 1779 & Joannes Josephus & Dąbrowski & Joachim & Wyszecka & Constantia \\
\hline 1779 & Joannes Antonius & Swichowski & Michael & Chmielińska & Marianna \\
\hline 1779 & Theresia Elisabetha & Bychowski & Michael & Paraska & Catharina \\
\hline 1779 & Michael Gorgonius & Kos & Michael & Zelewska & Joanna \\
\hline 1779 & Marianna & nieślubne & nieślubne & Lewińska & Dorothea \\
\hline 1779 & Joannes & Mach & Michael & Miszewska & Eva \\
\hline 1779 & Franciscus & nieślubne & nieślubne & Mauszycka & Victoria \\
\hline 1779 & Joanna Barbara & Wyszecki & Joannes & Swichowska & Barbara \\
\hline 1779 & Marianna Constantia & Gowiński & Joannes & Tempska & Victoria \\
\hline 1779 & Concordia Francisca & Wyszecki & Franciscus & Słuszewska & Catharina \\
\hline 1780 & Josephus & Welckowski & Mathias & Machowna & Marianna \\
\hline 1780 & Theresia Constantia & Wielestowski & Carolus & - & Constantia \\
\hline 1780 & Michael & Tempski & Michael & Kaszewska & Marianna \\
\hline 1780 & Gregorius Adalbertus & Ebel & Adalbertus & Mauszycka & Elisabetha \\
\hline 1780 & Alexander & Pobłocki & Antonius & Gowińska & Marianna \\
\hline 1780 & Adalbertus & Pobłocki & Antonius & Gowińska & Marianna \\
\hline 1780 & Marianna theressia & Zelewski & Antonius & Zelewska & Susanna \\
\hline 1780 & Marianna & Szmierowski & Adalbertus & Dąbrowska & Marianna \\
\hline 1780 & Joannes & nieślubne & nieślubne & Dąbrowska & Dorothea \\
\hline
\end{tabular}




\begin{tabular}{|c|c|c|c|c|c|}
\hline Rok & Imię dziecka & Nazwisko ojca & Imię ojca & $\begin{array}{c}\text { Nazwisko } \\
\text { rodowe matki }\end{array}$ & Imię matki \\
\hline 1780 & Michael beniamin & Tempski & Joannes & Wyszecka & Theresia \\
\hline 1780 & Apollonia Francisca & Zelewski & Michael & Borzestowska & Eleonora \\
\hline 1780 & Franciscus Jacobus & Mauszycki & Mathias & Robakowska & Constantia \\
\hline 1780 & Jacobus Adamus & Bychowski & Adalbertus & Gowińska & Victoria \\
\hline 1780 & Michael & nieślubne & nieślubne & Machowna & Dorothea \\
\hline 1780 & Franciscus & Swichowski & Franciscus & Lewińska & Marianna \\
\hline 1780 & Michael & Mach & Jacobus & Ustarbowska & Magdalena \\
\hline 1780 & córka & Tempski & Adalbertus & Wyszecka & Concordia \\
\hline 1780 & Marianna Ursula & Węsierski & Josephus & Lewińska & Catharina \\
\hline 1780 & Anna & Dobrzewiński & Jacobus & Lewińska & Ursula \\
\hline 1780 & Barbara & Szankin & Joannes & Mauszycka & Eva \\
\hline 1781 & Michael & Swichowski & Michael & Chmielińska & Marianna \\
\hline 1781 & Marianna & Dąbrowski & Joannes & Gowińska & Eva \\
\hline 1781 & Josephus Adamus & Tokarski & Jacobus & Zelewska & Anna \\
\hline 1781 & Michael & Swichowski & Joannes & Pobłocka & Dorothea \\
\hline 1781 & Francisca Marianna & Zelewski & Michael & Warzewska & Marianna \\
\hline 1781 & Concordia Birgitta & Dąbrowski & Joachim & Wyszecka & Constantia \\
\hline 1781 & Francisca & Kos & Michael & Zelewska & Joanna \\
\hline 1781 & Susanna & Studziński & Michael & Machowna & Catharina \\
\hline 1781 & Ursula Dorothea & Malotka & Michael & Kozłowska & Marianna \\
\hline 1781 & Josephina Catharina & Pobłocki & Antonius & Gowińska & Marianna \\
\hline 1781 & Antonius Josephus & Zelewski & Joannes & Warzewska & Barbara \\
\hline 1781 & Anna Catharina & Robakowski & Joannes & Ustarbowska & Catharina \\
\hline 1781 & Joachimus Carolus & Tempski & Adalbertus & Wyszecka & Concordia \\
\hline 1782 & Mathias & Mach & Michael & Miszewska & Eva \\
\hline 1782 & Joannes Antonius & Bychowski & Michael & Paraska & Catharina \\
\hline 1782 & Marianna & nieślubne & nieślubne & Mauszycka & Catharina \\
\hline 1782 & Jacobus & Ebel & Adalbertus & Mauszycka & Elisabeth \\
\hline 1782 & Josephina & Tempski & Michael & Kaszewska & Marianna \\
\hline 1782 & Jacobus Adalbertus & Gowiński & Joannes & Tempska & Victoria \\
\hline 1782 & Petrus & Mach & Jacobus & Miszewska & Magdalena \\
\hline 1782 & Dorothea Margaritha & Milke & Michael & Węsierska & Marianna \\
\hline 1782 & Teresia & Klata & Josephus & Albecka & Constantia \\
\hline 1782 & Marianna & Lewiński & Antonius & Frezowna & Theresia \\
\hline 1782 & Marianna & Malotka & Adalbertus & - & Alexandra \\
\hline 1782 & Marianna & Wylckowski & Mathias & - & Marianna \\
\hline 1783 & Victoria Josephina & Węsierski & Michael & - & Constantia \\
\hline 1783 & Antonius Teodorus & Zelewski & Antonius & - & Marianna \\
\hline 1783 & Heva & Kos & Michael & - & Anna \\
\hline 1783 & Anna & Kos & Michael & - & Anna \\
\hline 1783 & Marianna & Dobrzewiński & Jacobus & - & Ursula \\
\hline
\end{tabular}




\begin{tabular}{|c|c|c|c|c|c|}
\hline Rok & Imię dziecka & Nazwisko ojca & Imię ojca & $\begin{array}{c}\text { Nazwisko } \\
\text { rodowe matki }\end{array}$ & Imię matki \\
\hline 1783 & Adalbertus & Bychowski & Adalbertus & - & Victoria \\
\hline 1783 & Adalbertus & Albecki & Joannes & Ptakowna & Catharina \\
\hline 1783 & Anna Victoria & Gowiński & Joannes & - & Victoria \\
\hline 1783 & Teressia & Dąbrowski & Joannes & - & Eva \\
\hline 1783 & Constantia & Mauszicki & Mathias & - & Constantia \\
\hline 1783 & Antonius & Dąbrowski & Franciscus & - & Dorothea \\
\hline 1783 & Stanislaus & Malotka & Michael & - & Marianna \\
\hline 1783 & Lucas Thadeus & Tempski & Joannes & - & Theresia \\
\hline 1783 & Franciscus & Pobłocki & Antonius & - & Marianna \\
\hline 1783 & Constantia Marianna & Sychowski & Joannes & - & Dorothea \\
\hline 1783 & Marianna Barbara Theresia & Freza & Michael & - & Petronella \\
\hline 1784 & Constantia & Tempski & Michael & - & Marianna \\
\hline 1784 & Petrus & Welckowski & Mathias & - & Marianna \\
\hline 1784 & Francisca & Zelewski & Joannes & - & Barbara \\
\hline 1784 & Anna Eva & Szymirowski & Adalbertus & - & Anna \\
\hline 1784 & Josephus Benedictus & Wyszecki & Franciscus & Słuszewska & Catharina \\
\hline 1784 & Anna Josephina & Dąbrowski & Joachim & - & Constantia \\
\hline 1784 & Catharina Elisabeth & Studzieński & Michael & - & Catharina \\
\hline 1784 & Marianna & Jaskołka & Joannes & Machowna & Dorothea \\
\hline 1784 & Michael & Słuszewski & Joannes & Nowicka & Elisabetha \\
\hline 1785 & Zuzanna & Sychowski & Joannes & Pobłocka & Dorothea \\
\hline 1785 & Joannes Antonius & Robakowski & Joannes & 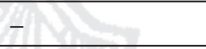 & Catharina \\
\hline 1785 & Ignatius & Tempski & Adalbertus & Wyszecka & Concordia \\
\hline 1785 & Brigitta Helena & Węsierski & Michael & Wyszecka & Constantia \\
\hline 1785 & Barbara Martianna & Koss & Joannes & - & Catharina \\
\hline 1785 & Martianna Catarina & Malotka & Michael & Kozłowska & Marianna \\
\hline 1786 & Anna & Lewiński & Antonius & Frezowna & Teresia \\
\hline 1786 & Susanna Dorothea & Zelewski & Antonius & Zelewska & susanna \\
\hline 1786 & Marcianna & Gowiński & Joannes & - & Victoria \\
\hline 1786 & Mathias & Miszewski & Christianus & - & Marianna \\
\hline 1786 & Marianna & Koss & Michael & Zelewska & Joanna \\
\hline 1786 & Apolonia & Tempski & Michael & Kaszewska & Marianna \\
\hline 1786 & Apolonia & Freza & Michael & Lewińska & Petronella \\
\hline 1786 & Teresia & Dobrzewiński & Jacobus & - & Barbara \\
\hline 1786 & Marianna & Zelewski & Joannes & Warzewska & Barbara \\
\hline 1786 & Josephina & Malotka & Adalbertus & - & Ludovica \\
\hline 1786 & Josephus & Dąbrowski & Joannes & - & Eva \\
\hline 1786 & Rozalia & Bychowski & Michael & - & Teressia \\
\hline 1786 & Teressia & Bychowski & Adalbertus & - & Victoria \\
\hline 1786 & Florianus & Dąbrowski & Franciscus & - & Dorothea \\
\hline 1786 & Joanna & Dobrzewiński & Ignatius & - & Constantia \\
\hline
\end{tabular}




\begin{tabular}{|c|c|c|c|c|c|}
\hline Rok & Imię dziecka & Nazwisko ojca & Imię ojca & $\begin{array}{c}\text { Nazwisko } \\
\text { rodowe matki }\end{array}$ & Imię matki \\
\hline 1786 & Martha Teressia & Tempski & Joannes & - & Teressia \\
\hline 1786 & Marianna & Węserski & Josephus & Zelewska & Anna \\
\hline 1786 & Dorothea & Mach & Michael & - & Heva \\
\hline 1786 & Adamus & Węsierski & Josephus & - & Barbara \\
\hline 1786 & Antonius Simon & Sychowski & Michael & Chmielińska & Marianna \\
\hline 1787 & Antonius Julianus & Sychowski & Joannes & Zelewska & Dorothea \\
\hline 1787 & Franciscus & Wilkowski & Mathias & - & Marianna \\
\hline 1787 & Dorothea & Lewiński & Antonius & - & Teressia \\
\hline 1787 & Joannes & Miszewski & Christianus & - & Marianna \\
\hline 1787 & Constantia & Koss & Joannes & - & Catharina \\
\hline 1787 & Constantia & Dąbrowski & Joachim & - & Constantia \\
\hline 1787 & Ignatius & Wyszecki & Franciscus & - & Concordia \\
\hline 1787 & Michael & Grabowski & Jacobus & - & Dorothea \\
\hline 1787 & Francisca & Koss & Michael & - & Joanna \\
\hline 1787 & Elisabetha & Studziński & Michael & - & Catharina \\
\hline 1787 & Antonius & Wyszecki & Joannes & - & Susanna \\
\hline 1788 & Antonius & Tempski & Michael & - & Marianna \\
\hline 1788 & Agatha & Paszk & Michael & - & Rosalia \\
\hline 1788 & Adalbertus Xawieri & Węsierski & Michael & - & Constantia \\
\hline 1788 & Josephina & Zelewski & Joannes & - & Barbara \\
\hline 1788 & Joannes & Sarnowski & Franciscus & - & Ludovica \\
\hline 1788 & Catharina & Wilkowski & Mathias & +2 & Marianna \\
\hline 1788 & Barbara Rozalia & Zelewski & Antonius & - & Susanna \\
\hline 1788 & Jacobus & Lebiatowski & Michael & 20 & Apolonia \\
\hline 1788 & Anna Barbara & Dąbrowski & Franciscus & - & Dorothea \\
\hline 1788 & Catharina & Lewiński & Adam & - & Teresia \\
\hline 1788 & Francisca & Koss & Adalbertus & - & Clara \\
\hline 1789 & Christianus Michael & Freyza & Michael & - & Petronella \\
\hline 1789 & Agnetha & Tempski & Joannes & Wyszecka & Teresia \\
\hline 1789 & Constantia agatha & Bychowski & Michael & Chmielińska & Teresia \\
\hline 1789 & Josephus & Lewiński & Josephus & Grubowna & Catharina \\
\hline 1789 & Barbara & Koss & Joannes & Małuszicka & Catharina \\
\hline 1789 & Teresia Anna & Sychowski & Michael & Chmielińska & Marianna \\
\hline 1789 & Franciscus Ignatius & Sychowski & Joannes & Zelewska & Dorothea \\
\hline 1789 & Marianna & Bychowski & Franciscus & Lewińska & Ewa \\
\hline 1789 & Joanna & Szimanski & Martinus & Bychowska & Barbara \\
\hline 1789 & Barbara & Szimanski & Martinus & Bychowska & Barbara \\
\hline 1789 & Anna & Bychowski & Adalbertus & Gowińska & Wiktoria \\
\hline 1789 & Adamus & Węsierski & Adamus & Zelewska & Ludovica \\
\hline 1789 & Marianna & Węsierski & Josephus & Zelewska & Barbara \\
\hline 1789 & Franciscus & Bychowski & Antonius & Dargolewska & Catharina \\
\hline
\end{tabular}




\begin{tabular}{|c|c|c|c|c|c|}
\hline Rok & Imię dziecka & Nazwisko ojca & Imię ojca & $\begin{array}{c}\text { Nazwisko } \\
\text { rodowe matki }\end{array}$ & Imię matki \\
\hline 1789 & Anna & Tempski & Michael & Kaszewska & Marianna \\
\hline 1789 & Marianna & Lewiński & Adam & Miszewska & Teresia \\
\hline 1790 & Francisca & Ebel & Adalbertus & Mauszycka & Elisabetha \\
\hline 1790 & Josephus & Wyszecki & Joannes & - & Susanna \\
\hline 1790 & Francisca & Malotka & Adalbertus & Machowna & Alexandra \\
\hline 1790 & Marianna & Węsierski & Adam & Zelewska & Ludovica \\
\hline 1790 & Franciscus Jacobus & Wyszecki & Franciscus & Słuszewska & Catharina \\
\hline 1790 & Rozalia & Studzieński & Michael & - & Catharina \\
\hline 1790 & Marianna & Węsierski & Michael & Wyszecka & Constantia \\
\hline 1790 & Franciscus & Kamiński & Franciscus & - & Marianna \\
\hline 1790 & Adamus & Lewiński & Antonius & - & Teresia \\
\hline 1790 & Clara Barbara & Gowiński & Joannes & - & Victoria \\
\hline 1790 & Franciscus & Gowiński & Josephus & Lewińska & Margaritha \\
\hline 1790 & Michael Ferdinandus & Zelewski & Antonius & Koziczkowska & Eleonora \\
\hline 1790 & Joannes Joachimus & Dąbrowski & Joachim & - & Constantia \\
\hline 1790 & Joannes Stephanus & Koss & Joannes & - & Catharina \\
\hline 1791 & Marianna & Malotka & Franciscus & Elentowa & Anna \\
\hline 1791 & Barbara Francisca & Pobłocki & Adalbertus & - & Leviza \\
\hline 1791 & Adalbertus & Borkowski & Adalbertus & - & Anna \\
\hline 1791 & Teresia Catharina & Sychowski & Joannes & Zelewska & Dorothea \\
\hline 1791 & Dorothea Magdalena & Bychowski & Franciscus & Machowa & Barbara \\
\hline 1791 & Marianna Efemia & Wyszecki & Franciscus & Pobłocka & Dorothea \\
\hline 1791 & Catharina & Węserski & Josephus & Zelewska & Barbara \\
\hline 1791 & Josephus & Freyza & Michaele & Lewińska & Petronella \\
\hline 1791 & Marianna & Tępski & Michael & Kaszewska & Marianna \\
\hline 1791 & Magdalena Anna & Bychowski & Antonius & Dargolewska & Elisabetha \\
\hline 1791 & Joannes & Bychowski & Adalbertus & Gowińska & Victoria \\
\hline 1791 & Michael & Dąbrowski & Franciscus & Wyszecka & Dorothea \\
\hline 1792 & Carolina Conkordya & Zelewski & Antonius & Koziczkowska & Eleonora \\
\hline 1792 & Franciscus & Wyszecki & Joannes & Bychowska & Rosalia \\
\hline 1792 & Josephus & Lewiński & Antonius & Sychowska & Teresia \\
\hline 1792 & teresia marianna & Malotka & Josephus & Chmielińska & Anna \\
\hline 1792 & Dorothea & Kmyn & Andreas & Kossowna & Anna \\
\hline 1792 & Dorothea & Albecki & Josephus & Rytowna & Marianna \\
\hline 1792 & Michael & Mach & Petrus & Tempska & Theresia \\
\hline 1792 & Anna Dorothea & Wilkowski & Mathias & Machowna & Marianna \\
\hline 1792 & Julianna Margaritha & Wierzbicki & Adalbertus & Słuszewska & Alexandra \\
\hline 1792 & Antonius & Gowiński & Joannes & Tempska & Victoria \\
\hline 1792 & Jacobus Joachimus & Wyszecki & Joannes & Lewińska & Florentina \\
\hline 1793 & Josphus & Węsierski & Adam & Zelewska & Ludovica \\
\hline 1793 & Joanna Francisca & Freza & Michael & Lewińska & Petronella \\
\hline
\end{tabular}




\begin{tabular}{|c|c|c|c|c|c|}
\hline Rok & Imię dziecka & Nazwisko ojca & Imię ojca & $\begin{array}{c}\text { Nazwisko } \\
\text { rodowe matki }\end{array}$ & Imię matki \\
\hline 1793 & Marcianna Leoviza & Wyszecki & Franciscus & Słuszewska & Catharina \\
\hline 1793 & Christina & Albecki & Josephus & Rytowna & Anna \\
\hline 1793 & Joanna & Mach & Petrus & Tempska & Teresia \\
\hline 1793 & Marianna Constantia & Dąbrowski & Joachim & Wyszecka & Konstantia \\
\hline 1793 & Joannes Ferdinandus & Węserski & Michael & Wyszecka & Constantia \\
\hline 1793 & Anna Apolonia & Malotka & Joseph & Chmielenska & Anna \\
\hline 1793 & Marianna Anna & Koss & Franciscus & Machowna & Barbara \\
\hline 1793 & Marianna & Studzieński & Michael & Machowna & Catharina \\
\hline 1793 & Josephus & Oss & Paulus & Albecka & Marianna \\
\hline 1793 & Dorothea & Wierzbicki & Adalbertus & Słuszewska & Alexandra \\
\hline 1793 & Franciscus & Szymanski & Franciscus & Bychowska & Barbara \\
\hline 1794 & Marianna & Gowiński & Josephus & Lewińska & Margaritha \\
\hline 1794 & Francisca & Koss & Joannes & Małuszicka & Catharina \\
\hline 1794 & Constantia & Sychowski & Joannes & Zelewska & Dorothea \\
\hline 1794 & Franciscus & Lewiński & Antonius & Frezowna & Teresia \\
\hline 1794 & Marianna & Sichowski & Michael & Chmielenska & Marianna \\
\hline 1794 & Jacobus & Węsierski & Josephus & Zelewska & Barbara \\
\hline 1794 & Francisca & Mach & \begin{tabular}{|l|} 
Joannes \\
\end{tabular} & - & Veronica \\
\hline 1795 & Eva & Albecki & Josephus & Szchreydrowna & Marianna \\
\hline 1795 & Anna Marianna & Zelewski & Michael & Jaszkowna & Marianna \\
\hline 1795 & Adalbertus & Wierzbicki & Adalbertus & Słuszewska & Alexandra \\
\hline 1795 & Apolonia & Studziński & Michael & - & Catharina \\
\hline 1795 & Dorothea & Kupiec & Michael & Chmielenska & Eleonora \\
\hline 1795 & Marianna & Bychowski & Adalbertus & Gowińska & Victoria \\
\hline 1795 & Susanna & Gowiński & Joannes & Tępska & Victoria \\
\hline 1795 & Anna & Sarnowski & Franciscus & Zielezińska & Lucia \\
\hline 1795 & Joannes Laurentius & Pobłocki & Michael & Ustarbowska & Dorothea \\
\hline 1795 & Anna & Koss & Joannes & Machowna & Barbara \\
\hline 1795 & Anna & Grabowski & Franciscus & Kozyczkowska & Eleonora \\
\hline 1795 & Marianna Barbara & Malotka & Josephus & Chmielińska & Anna \\
\hline 1795 & Anna Magdalena & Wyszecki & Antonius & Tokarska & Marianna \\
\hline 1796 & Barbara Anna & Słuszewski & Antonius & Tempska & Constantia \\
\hline 1796 & Anna & Mach & Petrus & Tempska & Theresia \\
\hline 1796 & Dorothea & Węsierski & Franciscus & Roykowna & Constantia \\
\hline 1796 & Anna Theressia & Borkowski & Adalbertus & Borkowska & Anna \\
\hline 1796 & Friderica Francisca & Tempski & Joannes & Wyszecka & Theresia \\
\hline 1796 & Joannes & Oss & Paulus & Albecka & Marianna \\
\hline 1796 & Ignatius Simon & Fryza & Michael & Częstkowska & Francisca \\
\hline 1796 & Martinus & Szymanski & Martinus & Bychowska & Barbara \\
\hline 1796 & Marianna & Węserski & Michael & Wyszecka & Constantia \\
\hline 1796 & Carolina Anna & Mach & Michael & Kożyczkowska & Concordia \\
\hline
\end{tabular}




\begin{tabular}{|c|c|c|c|c|c|}
\hline Rok & Imię dziecka & Nazwisko ojca & Imię ojca & $\begin{array}{c}\text { Nazwisko } \\
\text { rodowe matki }\end{array}$ & Imię matki \\
\hline 1796 & Dorothea & Sychowski & Joannes & Zielewska & Dorothea \\
\hline 1796 & $\begin{array}{l}\text { Constantia Marianna } \\
\text { Alexandra }\end{array}$ & Pobłocki & Michael & Ustarbowska & Dorothea \\
\hline 1797 & Alexander & Freza & Michael & Lewińska & Petronella \\
\hline 1797 & Anna & Gowiński & Josephus & Lewińska & Margarita \\
\hline 1797 & Josephina Marcianna & Koss & Franciscus & Podwelcowna & Barbara \\
\hline 1797 & Josephus Zacharias & Grabowski & Franciscus & Kożyczkowska & Eleonora \\
\hline 1797 & Marianna & Szwichtębarch & Michael & Padczinska & Elisabetha \\
\hline 1797 & Michael Antonius & Dobrzewiński & Antonius & - & Anna Rosalia \\
\hline 1797 & Adalbertus & Albecki & Josephus & Szreydrowna & Anna \\
\hline 1797 & Josephus Casimirus & Zielewski & Michael & Jaszkowna & Marianna \\
\hline 1797 & filia & Gowiński & Joannes & - & Victoria \\
\hline 1797 & Marianna & Mach & Joannes & Pobłocka & Veronica \\
\hline 1797 & Joannes Jacobus & Domreza & Fridericus & Balkowna & Marianna \\
\hline 1797 & Jacobus & Oss & Paulus & Albecka & Marianna \\
\hline 1797 & Francisca & Węsierski & Adam & Zielewska & Ludovica \\
\hline 1797 & Friderica Constantia & Wyszecki & Antonius & Tokarska & marianna \\
\hline 1797 & Joannes & Studzieński & Michael & Machowna & Catharina \\
\hline
\end{tabular}

mgr Anna Stachowska-Krzyżankowska Instytut Historii PAN

e-mail:ania@stachowska.com

\section{TAUFEN VON ADLIGEN IN DER PFARREI LUSIN \\ IN DER ZWEITEN HÄLFTE DES 18. JAHRHUNDERTS}

\section{Zusammenfassung}

Schlüsselwörter: altpolnische Demografie, kleinadlige Familie, Neuzeit, Kaschubien, Genealogie, Kleinadel, Kirchenbucheintragung, altpolnische Taufregister

Der Artikel ist das Ergebnis von Forschungen zur Genealogie und Demografie kleinadliger Familien in Kaschubien in der Neuzeit. Die Quellen in den Kirchenbüchern liefern reiches Forschungsmaterial, dessen eingehende Analyse es ermöglicht die demografischen Veränderungen zu beobachten, die in dieser Gesellschaft vor sich gingen. Obwohl die Pflicht zu regelmäßigen Eintragungen in Kirchenbüchern in der Mitte des 16. Jahrhunderts vom Konzil von Trient eingeführt wurde, kam es in Polen zur allgemeinen Einführung von Registern erst in der ersten Hälfte des 18. Jahrhunderts. Quellengrundlage des Artikels ist 
das Taufbuch der Pfarrei Lusin (Luzino) aus den Jahren 1758-1797. Die meisten Dörfer, die zu dieser Pfarrei gehörten, waren Eigentum des kaschubischen Kleinadels. Von den 3075 Taufen, die in dem Buch verzeichnet sind, wurden 15\% an Kindern von Adligen vollzogen. Der Artikel soll die demografischen Elemente erörtern, die sich bei einer genauen Analyse der Eintragungen im Register ermitteln ließen. Durch die Forschungen konnte u. a. die durchschnittliche Zahl von Taufen pro Jahr für einzelne Zeiträume von fünf Jahren festgestellt werden, sie vermittelten einen Einblick in die jahreszeitliche Verteilung von Empfängnissen und Geburten und in Zeit und Ort von Taufzeremonien. Der Artikel befasst sich auch mit dem Problem von außerehelichen Geburten in einzelnen Familien. Außerdem wurde versucht die Moden bei der Namensgebung im kaschubischen Adel des 18. Jahrhunderts zu betrachten, ebenso wie die Grundsätze, von denen man sich bei der Vornamengebung leiten ließ, und die Auswahl der Taufpaten.

\title{
BAPTISMS OF NOBLES IN THE PARISH CHURCH OF LUZINO IN THE SECOND HALF OF THE $18^{\text {TH }}$ CENTURY
}

\author{
Summary
}

Key words: the Old Polish demography, the family of minor noblemen, the Early Modern age, Kashubia, genealogy, minor noblemen, metrical registration, Old Polish baptismal certificates

This article is the fruit of research on the Kashubian genealogy and demography of a family of minor noblemen in the Early Modern period. Birth and baptismal certificates constitute a rich source of research material, whose thorough analysis enables us to observe the demographic changes taking place in a given community. Despite the fact that the obligation of regular birth and baptismal registration was introduced in the mid-1 $16^{\text {th }}$ century by the Council of Trent, in Poland birth and baptismal books did not become common until the first half of the 18th century. The source basis of the article is the book of baptisms in the parish church of Luzino from the years 1758-1797. Most villages belonging to the parish constituted the property of minor Kashubian noblemen. Out of 3075 baptisms recorded in the book, over $15 \%$ concerned the offspring of noble people. The aim of the article is to discuss those demographic elements, which could be captured in the process of the thorough analysis of birth and baptismal records. The research allowed us to define the average annual number of baptisms for subsequent five-year-long periods, to discover seasonality in conceptions and births, and to learn about the time and place of baptisms. The article also touches upon the issue of non-marital births in individual families and attempts to look at the onomastic trends among the $18^{\text {th }}$ century Kashubian noblemen and to reveal the rules they followed while chosing names and godparents for their children. 